\title{
EFFECTS OF NANOCURCUMIN IN RATS WITH DIABETES INDUCED WITH STREPTOZOTOCIN AND NICOTINAMIDE: MRNA EXPRESSION OF B-TYPE NATRIURETIC PEPTIDE
}

\author{
MARYAM ULFA ${ }^{1}$, DYAH SUCI HANDAYANI ${ }^{2}$, HOTLINA NAINGGOLAN ${ }^{2}$, WAWAIMULI AROZAL ${ }^{1 *}$
}

${ }^{1}$ Department of Pharmacology and Therapeutics, Faculty of Medicine, Universitas Indonesia, Jakarta, 10430, Indonesia. ${ }^{2}$ Biomedical Science Postgraduate Program, Faculty of Medicine, Universitas Indonesia, Jakarta, 10430, Indonesia. Email: wawaimulica@gmail.com

Received: 01 May 2018, Revised and Accepted: 09 November 2018

\section{ABSTRACT}

Objective: This study aimed to determine the effects of nanocurcumin on cardiomyopathy, assessed by the expression of B-type natriuretic peptide (BNP) mRNA in heart tissue.

Methods: Type 2 diabetic rats were induced with streptozotocin and nicotinamide. Nanocurcumin was orally administered (100 mg/kg/day) for 30 days. BNP-45 mRNA expression in the heart tissue was measured using quantitative reverse transcription-polymerase chain reaction and calculated using the Livak method.

Results: BNP-45 levels increased significantly $(\mathrm{p}<0.05)$ in diabetic rats compared with the normal group. Nanocurcumin treatment at a dose of $100 \mathrm{mg} / \mathrm{kg}$ for 30 days significantly decreased BNP-45 expression levels $(\mathrm{p}<0.05)$ compared with diabetic rats without treatment.

Conclusion: Nanocurcumin may be beneficial in inhibiting the progression of diabetic cardiomyopathy by suppressing the expression of BNP-45.

Keywords: B-type natriuretic peptide-45, Nanocurcumin, Nicotinamide, Streptozotocin.

(C) 2018 The Authors. Published by Innovare Academic Sciences Pvt Ltd. This is an open access article under the CC BY license (http://creativecommons. org/licenses/by/4. 0/) DOI: http://dx.doi.org/10.22159/ijap.2018.v10s1.38

\section{INTRODUCTION}

Diabetes mellitus (DM) is a metabolic disease characterized by hyperglycemia caused by insulin secretion abnormalities [1]. In Indonesia, the prevalence of diabetes increased from $5.7 \%$ of the overall population in 2007-6.9\% in 2013 [2]. This increased incidence of DM is most certainly accompanied by complications. Chronic hyperglycemia in patients with uncontrolled diabetes leads to the development of high levels of reactive oxygen species (ROS) and pro-inflammatory cytokines, which can cause cell dysfunction in various organs including heart tissue [3-5]. Indeed, diabetic cardiomyopathy is characterized by dilatation and hypertrophic myocardium, resulting in decreased systolic and diastolic ventricle function [5].

B-type natriuretic peptide (BNP) levels are considered an objective and specific measurement to diagnose and evaluate therapies for cardiac failure [6]. BNP is a specific cardiac neurohormone that increases in response to hypertrophy and dilatation of the myocardium $[7,8]$. Treatments for hypertrophic cardiomyopathy are still being developed and include herbal medicines. One such herbal medicine is curcumin, an active substance obtained from Curcuma longa, which is an indigenous plant of Indonesia [9]. Previous studies have shown that curcumin has anti-inflammatory, antioxidant, and antiproliferative properties [9-11]. Therefore, it may be promising as an adjunctive treatment of type 2 diabetes by inhibiting its progression [11]. Unfortunately, the therapeutic usage of curcumin is limited due to its low bioavailability. However, a previous study has reported that the bioavailability of curcumin increases in the form of nanoparticles $[12,13]$.

Previously, oral administration of nanocurcumin $(100 \mathrm{mg} / \mathrm{kg}$ body weight per day for 30 days) appeared to suppress ROS levels in rats with diabetic cardiomyopathy [14]. However, no research on the effects of nanocurcumin on diabetic cardiomyopathy in rats has been conducted. Thus, this study aimed to investigate the effects of nanocurcumin on diabetic cardiomyopathy in rats induced with streptozotocin and nicotinamide, in an effort to enrich the use of Indonesian natural medicines.
This study aimed to analyze the effects of nanocurcumin on diabetic cardiomyopathy through the examination of BNP-45 mRNA expression in the heart tissue of diabetic rats induced with streptozotocin and nicotinamide.

\section{METHODS}

Materials

RNA isolation, cDNA synthesis, and reverse transcription polymerase chain reaction (RT-PCR) kits were purchased from Roche.

\section{Animals}

Male Sprague-Dawley rats weighing 150-300 g, obtained from LITBANGKES (Jakarta, Indonesia), were used. The rats were kept in a room with constantly controlled temperature, humidity, and lighting. They were provided food and water ad libitum.

\section{Nanocurcumin preparation}

Nanocurcumin was obtained from PT. Nanotech Puspitek (Serpong, Indonesia). It was orally administered at a dose of $100 \mathrm{mg} / \mathrm{kg}$ body weight per day for 30 days.

\section{Experimental design}

The dosing and schedule of nanocurcumin treatment in rats has been described in a previous study [15]. The rats were divided into three groups: Normal, diabetic, and diabetic rats treated with nanocurcumin. Nanocurcumin was administered orally at a dose of $100 \mathrm{mg} / \mathrm{kg} /$ day for 30 days. Rat heart tissue was stored at $-80^{\circ} \mathrm{C}$ until analysis.

\section{RNA isolation}

Heart tissue was homogenized using an Ultra Turrax electric homogenizer. Total RNA was isolated from heart tissue homogenate using the TriPure ${ }^{\circledR}$ reagent (Roche) according to the manufacturer's protocol. Isolated RNA concentration and purity were measured with a Nanodrop 2000 (Thermo Scientific). 
cDNA synthesis

The cDNA synthesis reaction was performed using a Transcriptor First Strand cDNA Synthesis Kit (Roche). The concentration and purity were measured spectrophotometrically at $260 \mathrm{~nm}$ using a Nanodrop 2000 (Thermo Scientific).

\section{Examination of BNP-45 mRNA expression}

The mRNA expression of BNP-45 in heart tissue was measured by quantitative RT-PCR and calculated by the Livak method. RT-PCR was conducted using the FastStart Essential DNA Green Master (Roche) kit on a LightCycler Nano (Roche). Primers and temperatures used for amplification are presented in Table 1.

The expression of mRNA was automatically calculated by the software to get a threshold value (Ct). The value was then calculated by the Livak method based on $2-\Delta \Delta \mathrm{Ct}$ to obtain the level of mRNA expression.

\section{Production of heart homogenates for the determination of BNP-45} levels

Whole heart tissues were cut and weighted at 100-120 mg and placed into a glass mortar. The mixture of tissue with phosphate-buffered saline at 9 times the volume, along with $5 \mu \mathrm{L}$ of protease inhibitor solution, was homogenized using a mortar and pestle. The homogenate was centrifuged at $12,000 \times \mathrm{g}$ for $15 \mathrm{~min}$ at $4^{\circ} \mathrm{C}$, and the supernatant was obtained. Pellets were then washed by isopropanol and centrifuged at $7500 \times \mathrm{g}$ for $5 \mathrm{~min}$. RNase-free water was added after removing the supernatant, and the mixture was incubated at $60^{\circ} \mathrm{C}$ for $15 \mathrm{~min}$. The RNA was then used for the preparation of cDNA using $4 \mu \mathrm{L}$ of transcript reverse transcriptase reaction buffer, $0.5 \mu \mathrm{L}$ RNAase inhibitor protector $(40 \mathrm{U} / \mu \mathrm{L}), 2 \mu \mathrm{L}$ Deoxynucleotide mix $(10 \mathrm{mM})$, and transcriptase reverse transcriptase $(10 \mathrm{U} / \mu \mathrm{L})$. The tube was placed in a thermal block cycler at $65^{\circ} \mathrm{C}$ for $10 \mathrm{~min}, 25^{\circ} \mathrm{C}$ for $10 \mathrm{~min}$, and $55^{\circ} \mathrm{C}$ for $5 \mathrm{~min}$.

\section{Measurement of BNP-45 level}

Measurement of BNP-45 levels was conducted using the RT-PCR method with the RT-PCR SYBR $®$ Green Supermix kit.

\section{Statistical analysis}

The data obtained were analyzed using the Statistical Package for the Social Sciences version 20. One-way analysis of variance was used for comparisons among groups, followed by post hoc test least significant difference. $\mathrm{p}<0.05$ was considered to be statistically significant.

\section{RESULTS AND DISCUSSION}

BNP-45 expression analysis results are depicted in Fig. 1. BNP-45 levels increased significantly $(\mathrm{p}<0.05)$ in diabetic rats compared with the normal group. Nanocurcumin treatment at a dose of $100 \mathrm{mg} / \mathrm{kg}$ for 30 days significantly decreased BNP-45 expression levels $(\mathrm{p}<0.05)$ compared with diabetic rats without treatment.

Diabetic cardiomyopathy is a cardiovascular disorder characterized by chronic hyperglycemia in diabetic patients [3]. Accordingly, the myocardium becomes hypertrophied and dilated and increased BNP is secreted to maintain cardiovascular homeostasis. Indeed, BNP is a specific cardiac neurohormone that can be an objective and simple measurement for diagnosing and evaluating therapies for cardiac failure. Our results indicate that BNP-45 levels in diabetic rats were higher than in normal rats. This is likely because the diabetic rats had cardiomyopathy and the hypertrophic myocardium expressed BNP-45 to a greater extent [15]. Hypertrophy causes myocardium stretching, which triggers the expressions of BNP into the bloodstream to maintain cardiovascular homeostasis. When the cardiovascular load increases and fails in overall function, the second line of protection will be activated to speedup BNP transcription. Therefore, levels of BNP mRNA in heart tissue will increase [16].

The progression of cardiomyopathy can be inhibited by administering an antioxidant $[11,15]$. One such antioxidant is curcumin, an active substance from Curcuma longa that has been proven to suppress
Table 1: Primer sequences and temperatures of BNP-45 and $\beta$-actin

\begin{tabular}{ll}
\hline Gene & Primer sequence $^{17}$ \\
\hline BNP-45 & F: $5^{\prime}$-TGG-GCA-GAA-GAT-AGA-CCG-GA-3' $\mathrm{Tm}(\mathrm{C}): 60.03^{\circ} \mathrm{C}$ \\
& R: $5^{\prime}$-ACA-ACC-TCA-GCC-CGT-CAC-AG-3' Tm (C): $62.38^{\circ} \mathrm{C}$ \\
\multirow{3}{*}{-actin } & F: $5^{\prime}$-CGT-CAT-CCA-TGG-CGA-ACT-3' $\mathrm{Tm}(\mathrm{C}): 57.48^{\circ} \mathrm{C}$ \\
& R: $5^{\prime} \mathrm{CCC}^{\prime}$ GCG-AGT-ACA-ACC-TTC-T-3' $\mathrm{Tm}$ (C): $59.41^{\circ} \mathrm{C}$ \\
\hline \multirow{2}{*}{ BNP-45: B-type natriuretic peptide-45 }
\end{tabular}

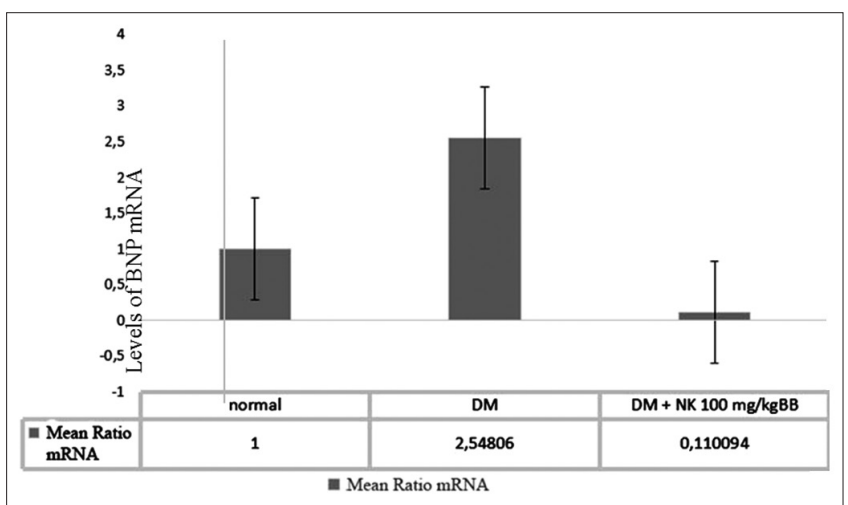

Fig. 1: B-type natriuretic peptide-45 mRNA levels in all three treatment groups. Data are presented as mean \pm standard deviation. ${ }^{*} \mathrm{p}=0.006,{ }^{* *} \mathrm{p}=0.032$ after one-way analysis of variance followed by the least significant difference post hoc test at $\alpha=0.05$.

Diabetes mellitus (DM), diabetic group; DM+NK, diabetic rats with nanocurcumin treatment

the progression of type 2 DM [11]. In a previous study, curcumin in nanoparticles at a dose of $100 \mathrm{mg} / \mathrm{kg}$ for 30 days suppressed ROS levels in diabetic rats [15]

According to our results, oral treatment with nanocurcumin at a dose of $100 \mathrm{mg} / \mathrm{kg}$ for 30 days in diabetic rats resulted in lower mRNA BNP45 expression than diabetic rats that were not treated. This shows that the treatment of nanocurcumin decreased the expression of BNP-45 in rats experiencing cardiomyopathy. These findings are in accordance with previous research demonstrating significant improvement of heart tissue damage in rats treated for myopathy [15]. It is also in line with another study that confirmed that nanocurcumin is an antioxidant and anti-inflammatory with good cardiovascular effects, particularly in reducing migration and growth of uncontrolled vascular smooth muscle cells under hyperglycemic conditions [14].

\section{CONCLUSION}

Collectively, our findings indicate that nanocurcumin has beneficial effects in inhibiting the progression of diabetic cardiomyopathy by suppressing the expression of BNP-45 mRNA. Moreover, a dose of $100 \mathrm{mg} / \mathrm{kg}$ for 30 days of nanocurcumin treatment significantly decreased BNP-45 expression levels. This shows that the treatment of nanocurcumin decreased the expression of BNP-45 in rats experiencing cardiomyopathy.

\section{CONFLICTS OF INTEREST}

All authors declare that they have no conflicts of interest.

\section{REFERENCES}

1. Purnamasari D. Texbook of Internal Medicine. Jakarta: Internal Publishing; 2014. p. 2323.

2. Indonesian Ministry of Health. Situation and Analysis of Diabetes. Jakarta: Data and Information Center; 2014.

3. Waspadji S. Textbook of Internal Medicine. Jakarta: Internal Publishing; 2014 
4. Powers AC, In Harrison's Endocrinology. 17 $7^{\text {th }}$ ed. New York: McGrawHill; 2008. p. 267.

5. Shahab A. Texbook of Internal Medicine. Jakarta: Internal Publishing; 2014.

6. Maisel AS, Krishnaswamy P, Nowak RM, McCord J, Hollander JE, Duc $\mathrm{P}$, et al. Rapid measurement of B-type natriuretic peptide in the emergency diagnosis of heart failure. N Engl J Med 2002;347:161-7.

7. Pappachan JM, Varughese GI, Sriraman R, Arunagirinathan G. Diabetic cardiomyopathy: Pathophysiology, diagnostic evaluation and management. World J Diabetes 2013;4:177-89.

8. Takei Y. B-Type natriuretic peptide (BNP) and C-type natriuretic peptide (CNP). In: Handbook of Biologically Active Peptides. Vol. 10. London: Elsevier; 2006. p. 805-12.

9. Jurenka JS. Anti-inflammatory properties of curcumin, a major constituent of curcuma longa: A review of preclinical and clinical research. Altern Med Rev 2009;14:141-53.

10. Jayaprakasha GK, Rao LJ, Sakariah KK. Antioxidant activities of curcumin, demethoxycurcumin and bisdemethoxycurcumin. Food Chem 2006;98:720-4.

11. Chuengsamarn S, Rattanamongkolgul S, Luechapudiporn R,
Phisalaphong C, Jirawatnotai S. Curcumin extract for prevention of Type 2 diabetes. Diabetes Care 2012;35:2121-7.

12. Anand P, Kunnumakkara AB, Newman RA, Aggarwal BB. Bioavailability of curcumin: Problems and promises. Mol Pharm 2007;4:807-18.

13. Ochekpe NA, Olorunfemi PO, Ngwuluka NC. Nanotechnology and drug delivery Part 1: Background and applications. Trop J Pharm Res 2009;8:265-74.

14. Wang YJ, Lin HY, Wu CH, Liu DM. Forming of demethoxycurcumin nanocrystallite-chitosan nanocarrier for controlled low dose cellular release for inhibition of the migration of vascular smooth muscle cells. Mol Pharm 2012;9:2268-79.

15. Nainggolan H. The Effect of Oral Nanokurkumin on Mice with Diabetic Cardiomyopathy Focused on Oxidative Stress Resistance. Jakarta: Pharmacology and Therapeutics Departement Faculty of Medicine Universitas Indonesia; 2016.

16. Ferdinal F, Suyatna FD, Wanandi SI, Sadikin M. Expression of B-type natriuretic peptide-45 (BNP-45) gene in the ventricular myocardial induced by systemic chronic hypoxia. Acta Med Indones 2009;41:136-43 